\title{
Anchorage strength and ductility in shear tests
}

\author{
Aleksandr Shuvalov, Igor Gorbunov, and Mikhail Kovalev* \\ Moscow State University of Civil Engineering, Yaroslavskoe shosse, 26, Moscow, 129337, Russia
}

\begin{abstract}
Article shows shear tests results for anchorage using bent foundation bolts 16,24 and $36 \mathrm{~mm}$ in diameter and torque-controlled undercut anchors 12, 16 and $20 \mathrm{~mm}$ in diameter. Load-displacement diagrams were acquired for shear loads in static and dynamic cyclic tests in uncracked and cracked concrete. Cyclic loading pattern simulated seismic loads on anchors. Shear loading tests allowed to estimate influence of cracks and cyclic loading on strength and ductility of anchorage.
\end{abstract}

\section{Introduction}

Anchorage strength and ductility research was carried out in three stages. On the first stage of tests [1] minimum embedment depth was determined for three diameters of bent anchor bolts in concrete blocks with strength grade B30 [2, 3]. Embedment depth for torquecontrolled undercut anchors was established according to specification [4]. Pullout test results from concrete blocks for anchors including deformation curves (load-displacement diagrams) were used as basic data for analysis of influence of the following factors on deformation curve:

1. crack existence in concrete block, which has high probability of occurring during seismic action according to many researchers [5-11]. Based on [8] value of residual width of cracks after earthquake action alternated between 0.26 and $1.04 \mathrm{~mm}$ for cracks located in columns and beams of different cross-section;

2. dynamic loading simulating seismic loading according to $[12,13]$;

3. change of loading conditions (present research on the third stage - shear testing). Necessity for such tests and testing procedure are shown in $[8,12,14-16]$.

Pullout strength depends on embedment depth determined by concrete and steel strength, whereas shear anchorage strength is determined by steel bolt strength with possible crushing of concrete and local concrete cone failure in conditions of combined stress for anchor in cracked concrete during cyclic shear $[8,16]$. Structural resistance of anchorage in shear tests was estimated using absolute and relative strength and displacement indexes [17].

Present research results for strength and ductility in shear tests combined with pullout tests results [1] can be used in seismic design for two types of anchorage for structure and equipment in concrete base. Also, there is a possibility of test execution based on limited scheme developed in testing procedure: carrying out static tests for pullout and (or) shear

\footnotetext{
* Corresponding author: kovalyov.mike@gmail.com
} 
using acquired data on influence of cracks and dynamic loading on anchorage deformation curve.

\section{Methods and materials}

During test preparations [18] bent foundation bolts were installed into drilled holes in preformed concrete blocks (figure 1). Sizes of drilled holes were chosen in accordance with anchor diameter (table 1). Self-expanding cement-sand grout with strength grade B50 [2] was used for anchor embedment in wells. Its expansion in unrestricted conditions was $0.06 \ldots 0.08 \mathrm{~mm} / \mathrm{m}$.

Table 1. Geometry parameters for bent anchors cast in well.

\begin{tabular}{|c|c|c|c|}
\hline Bolt diameter $d, \mathrm{~mm}$ & 16 & 24 & 36 \\
\hline Well depth $H_{K}, \mathrm{~mm}$ & $H_{0}+10$ & $H_{0}+10$ & $H_{0}+10$ \\
\hline Well diameter $D_{K}, \mathrm{~mm}$ & 82 & 122 & 152 \\
\hline Fixture thickness $t, \mathrm{~mm}$ & 40 & 40 & 50 \\
\hline
\end{tabular}

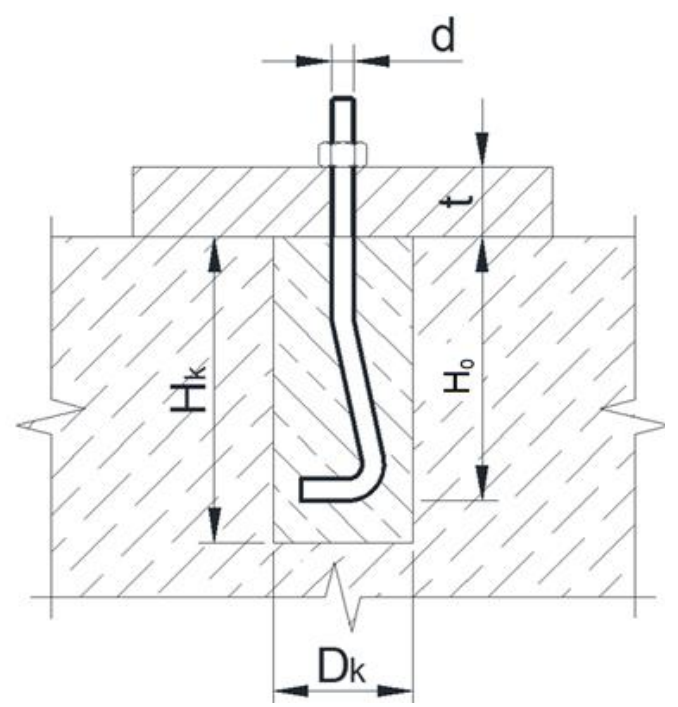

Fig. 1. Cast-in-place bent foundation bolt.

Hole drilling for installation of torque-controlled undercut anchors (figure 2) was done till necessary depth $\mathrm{H}_{0}$ [4] using drill bit with stopper (fixture thickness $\mathrm{t}=40 \mathrm{~mm}$ ) [4].

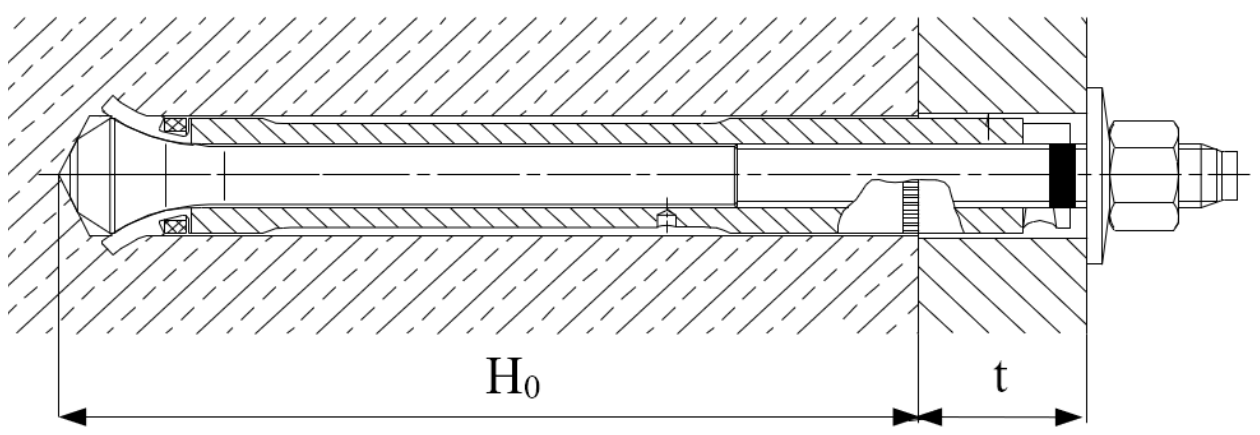

Fig. 2. Torque-controlled undercut anchor. 
Concrete blocks of various size with concrete grade B30 were used as base for anchor embedment. Steel tension strength for bent bolts was 500-600 MPa, for undercut anchors 800-850 MPa. Blocks were reinforced with structural reinforcement [3] to exclude failure of concrete base during crack formation.

Force from load frame to anchor was transferred using steel plate (figure 3). Specimens loading was done using rearranging load frame CFM Schiller equipped with MTS hydrocylinders. «Load-displacement» diagram was recorded during tests. Displacement measurement was carried out using linear displacement gauge SPD-100C manufactured by Tokyo Sokki Kenkyujo with measurement limit of $100 \mathrm{~mm}$ and measuring sensitivity of $0.01 \mathrm{~mm}$.

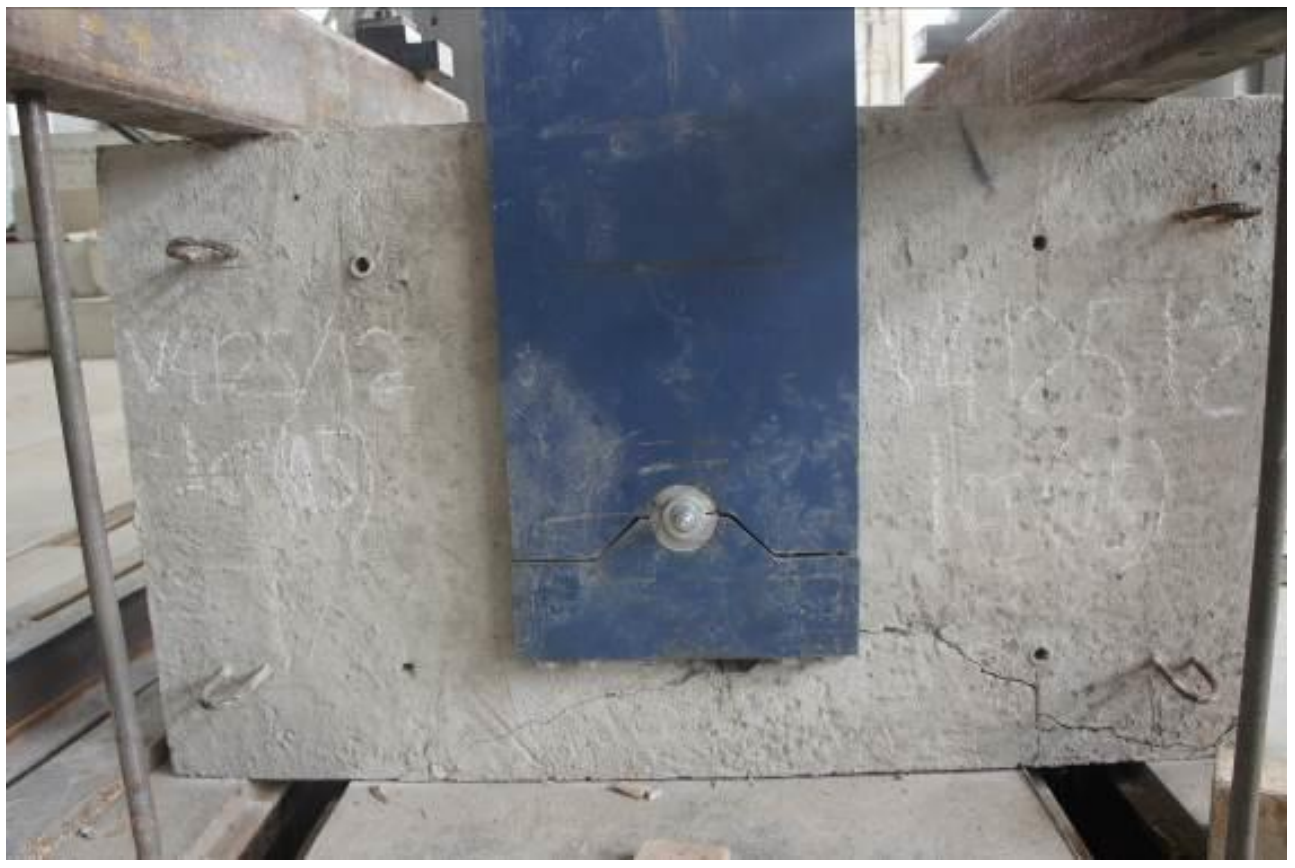

Fig. 3. Rig for anchor shear tests.

Crack was formed using tapered steel elements. Crack width was controlled using dial displacement gauge with division value of $0.01 \mathrm{~mm}$.

Seismic loading was simulated in cyclic load tests according to regulatory documents [12]. Table 2 and figure 4 show loading pattern $\left(\mathrm{V}_{\max }=0,425 \cdot \mathrm{V}_{\mathrm{u}, \mathrm{m}} ; \mathrm{V}_{\mathrm{u}, \mathrm{m}}\right.$ - ultimate shear strength acquired in static tests with crack width of $\Delta \mathrm{w}=1,5 \mathrm{~mm}$ ). Load frequency was 0,5 $\mathrm{Hz}$.

Table 2. Load amplitude for cyclic tests.

\begin{tabular}{|c|c|c|c|c|c|c|c|c|c|c|}
\hline $\mathrm{V} / \mathrm{V}_{\max }$ & 0,2 & 0,3 & 0,4 & 0,5 & 0,6 & 0,7 & 0,8 & 0,9 & 1,0 & Total \\
\hline $\begin{array}{c}\text { Number } \\
\text { of cycles }\end{array}$ & 25 & 15 & 5 & 5 & 5 & 5 & 5 & 5 & 5 & 75 \\
\hline
\end{tabular}




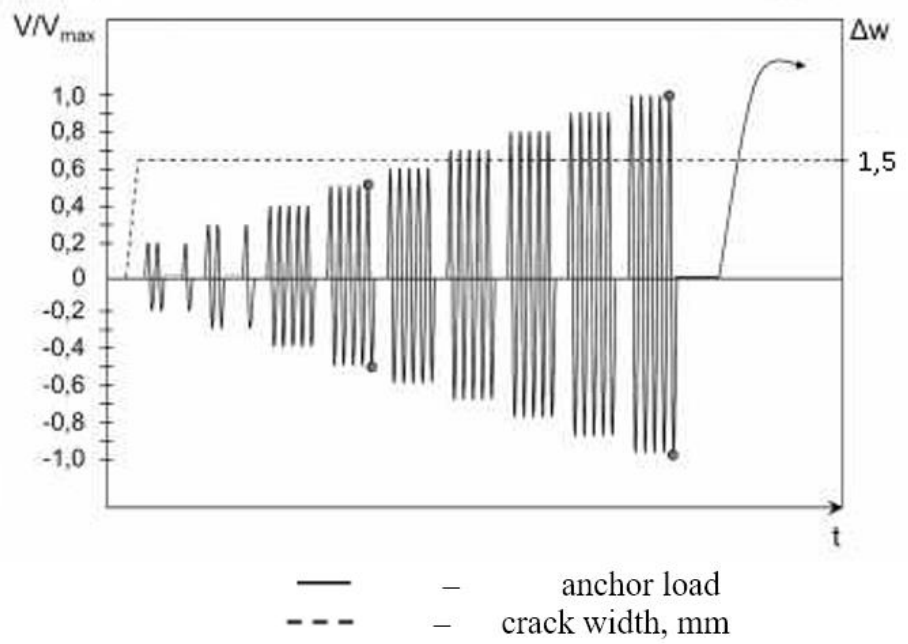

Fig. 4. Cyclic tests loading pattern.

\section{Test results}

Figure 5 shows typical «Load-displacement» diagrams for bent anchor bolts mounted in cracked and uncracked concrete with strength grade B30 under static load. Figure 6 shows typical «Load-displacement» diagram for bent foundation bolts under dynamic load which simulated seismic load with following static loading till failure.

Figure 7 shows typical «Load-displacement» diagrams for torque-controlled undercut anchors mounted in cracked and uncracked concrete with strength grade B30 under static load. Figure 8 shows typical «Load-displacement» diagram for torque-controlled undercut anchor under dynamic load which simulated seismic load with following static loading till failure.

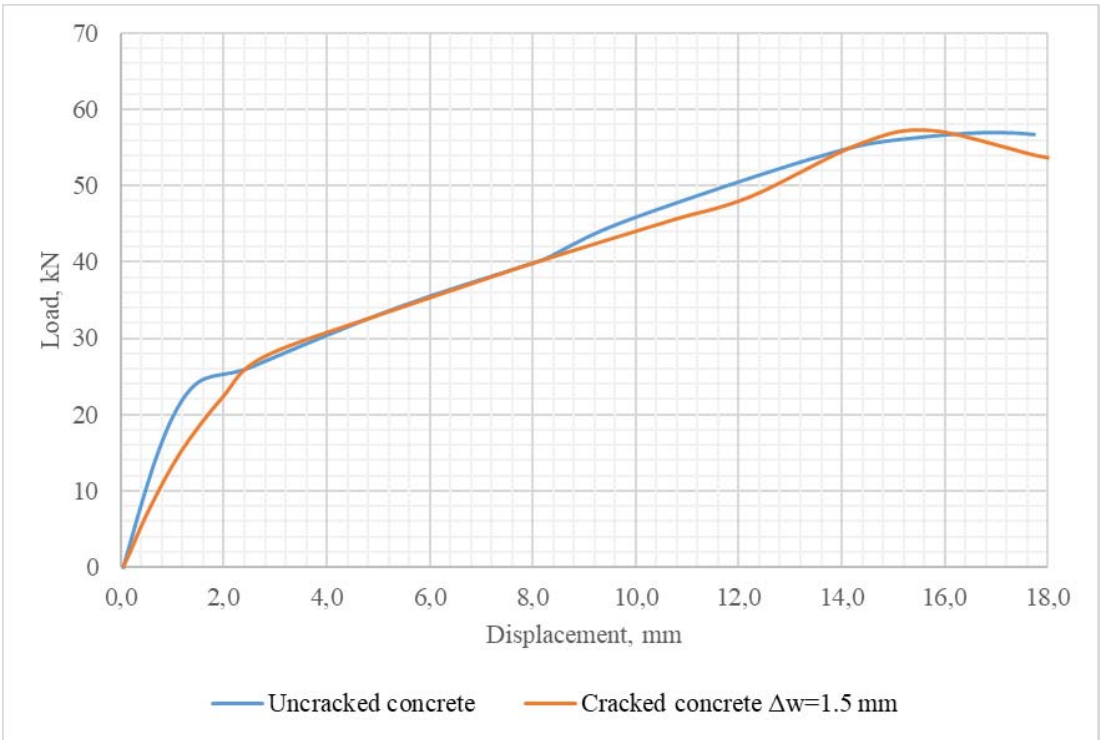

Fig. 5. «Load-displacement» diagrams for bent foundation bolt $16 \mathrm{~mm}$ in diameter under static load. Embedment depth $-200 \mathrm{~mm}$. Steel strength $\mathrm{R}=600 \mathrm{MPa}$. 


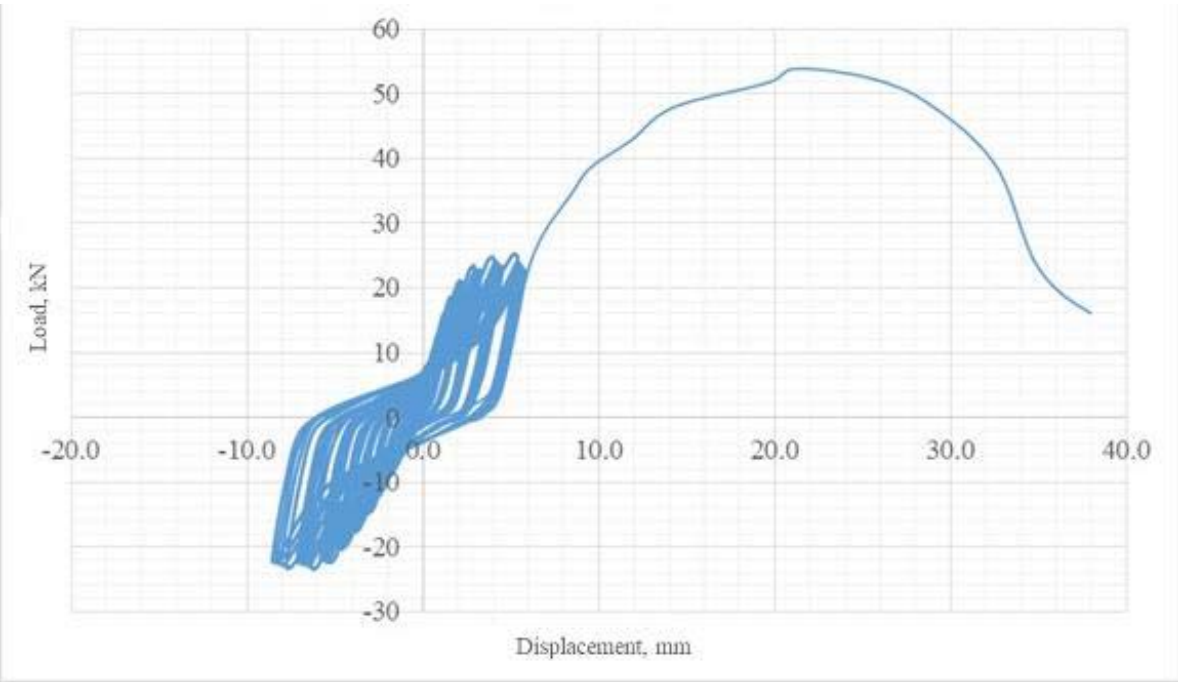

Fig. 6. «Load-displacement» diagram for bent foundation bolt $16 \mathrm{~mm}$ in diameter under dynamic load. Embedment depth $-200 \mathrm{~mm}$. Steel strength $\mathrm{R}=600 \mathrm{MPa}$.

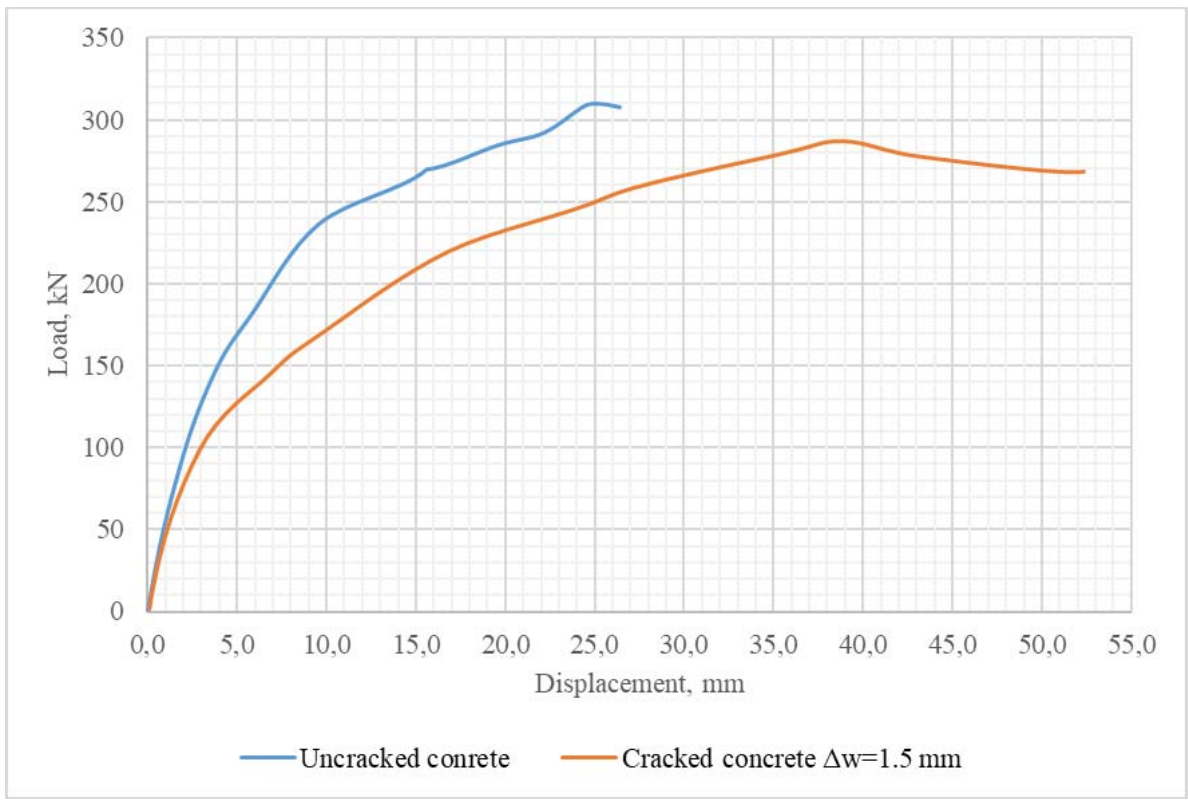

Fig. 7. «Load-displacement» diagrams for undercut anchor $16 \mathrm{~mm}$ in diameter under static load. Embedment depth $-190 \mathrm{~mm}$. Shear design cross-section $6.605 \mathrm{~cm}^{2}$. 


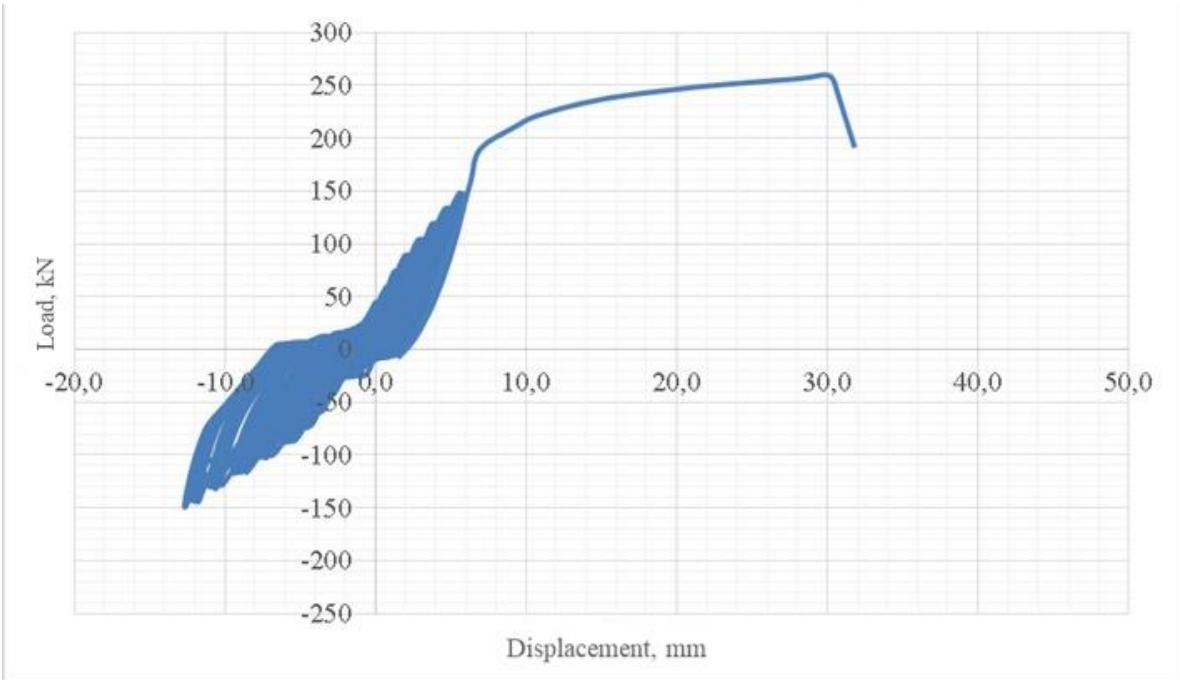

Fig. 8. «Load-displacement» diagram for undercut anchor $16 \mathrm{~mm}$ in diameter under dynamic load. Embedment depth $-190 \mathrm{~mm}$. Shear design cross-section $6.605 \mathrm{~cm}^{2}$.

\section{Discussion}

According to comparative analysis of behavior of bent anchor bolts $16 \mathrm{~mm}$ in diameter, difference in embedment depth in range of 150-200 $\mathrm{mm}$ has no impact on strength and ductility of anchorage in shear tests.

Analysis of deformation curves acquired for bent anchor bolts in shear tests shows:

- in static shear tests existence of crack in concrete block scarcely influences strength of anchorage but leads to increase in ductility on particular loading stages;

- dynamic shear loading in cracked concrete results in decrease in anchorage strength by up to $7 \%$ and increase in displacements at ultimate load by up to $36 \%$.

Analysis of deformation curves acquired for torque-controlled undercut anchors in shear tests shows:

- existence of crack in concrete block results in decrease in anchorage strength by 7 $25 \%$;

- in static shear tests existence of crack on concrete block leads to increase in displacement at ultimate load by up to $56 \%$ for anchor with shear design cross-section of $6.6 \mathrm{~cm}^{2}$;

- dynamic shear loading in cracked concrete is accompanied by decrease in anchorage strength by $14-28 \%$ in comparison to static shear loading in uncracked concrete.

Ultimate load in pullout tests is determined by nominal diameter of anchor bolts and steel strength. Design diameter for two types of anchors is chosen based on its tension strength. In shear tests difference in effective sections and steel strength leads to significant exceedance (more than 4.5 times) of torque-controlled undercut anchors strength over bent anchor bolts strength. As a result, it is sensible to make comparison of anchorage ductility for two types of anchor using diagrams with relative values of loads. Absolute displacement at ultimate load for torque-controlled undercut anchors is 2.5 times higher than the one for bent anchor bolts (figure 9). Comparative diagrams for anchorage in shear tests can be acquired if both axes: load and displacement, are relative (figure 10). Contribution to common displacement from strain of concrete and steel bolt at high loads is higher for torque-controlled undercut anchors than for bent anchor bolts. Relative displacements for 
torque-controlled undercut anchors on loading stage of $0.8-1.0 \cdot \mathrm{V}_{\text {ult }}$ were $50 \%$, while for bent anchor bolts $-30 \%$.

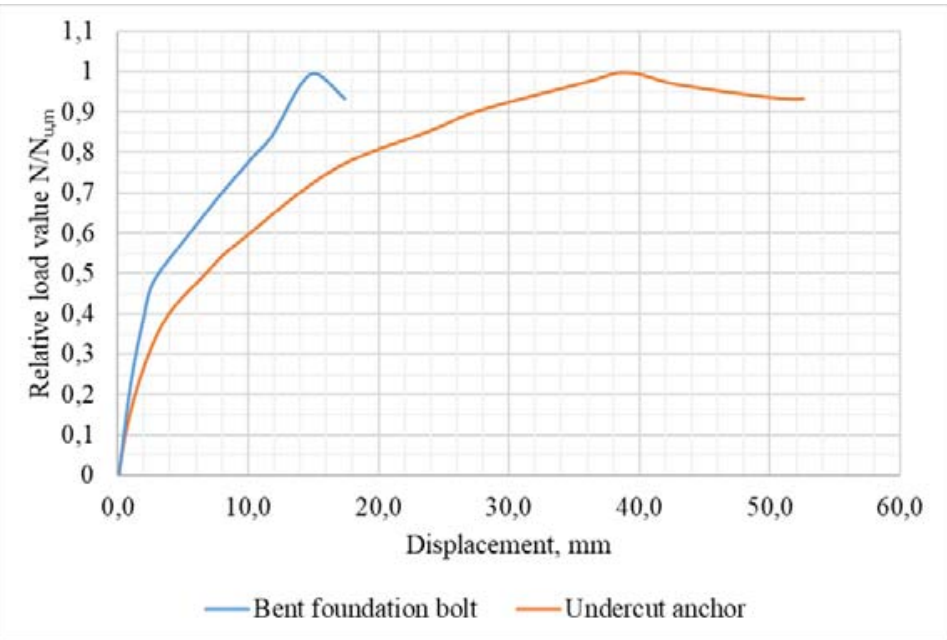

Fig. 9. Comparison of absolute displacements acquired in tests of anchors $16 \mathrm{~mm}$ in diameter in cracked concrete.

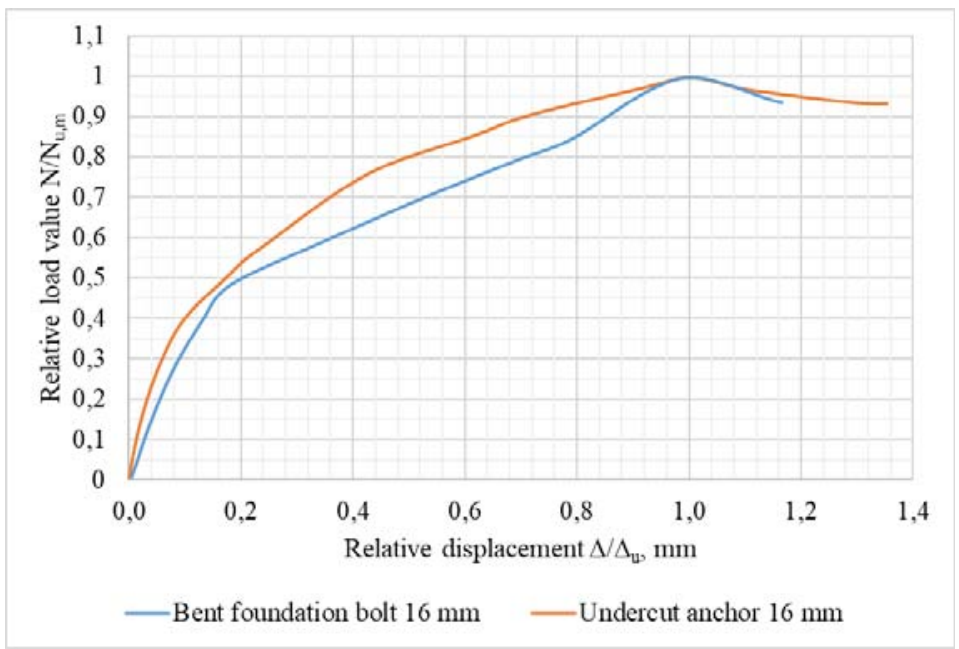

Fig. 10. Comparison of relative displacements acquired in tests of anchors $16 \mathrm{~mm}$ in diameter in cracked concrete.

\section{Conclusions}

1. Minimal anchor embedment depth established in tests [1] guarantees steel fracture for anchors in shear tests. Steel strength determines anchor strength in shear tests.

2. During anchorage shear tests there were anchor displacements up to $40 \mathrm{~mm}$ for bent anchor bolts $36 \mathrm{~mm}$ in diameter and torque-controlled undercut anchors 12,16 and $20 \mathrm{~mm}$ in diameter. These values of displacement are inadmissible by service conditions and are followed by local concrete cone failure.

3. In comparison to pullout tests results [1], in shear tests cracks and dynamic loading lead to decrease in anchorage strength: 
- in case of bent anchor bolts strength decrease by up to $7 \%$ is seen only during combination of cracks and dynamic loading;

- in case of torque-controlled undercut anchors anchorage strength in static shear tests in cracked concrete decreases by up to $25 \%$;

- dynamic shear loading for torque-controlled undercut anchors in cracked concrete leads to decrease in anchorage strength by up to $28 \%$.

\section{References}

1. A.N. Shuvalov, I.A. Gorbunov, M.G. Kovalev Anchorage strength and ductility at various loading conditions in Proceedings of FORM-2020, 23-26 September 2020, Hanoi, Viet Nam, (2020)

2. MDS 3142000 Posobie po proektirovaniyu ankernyh boltov dlya krepleniya stroitelnyh konstruktsij i oborudovaniya k SNiP 20903

3. GOST 2437912012 Bolty fundamentnye. Konstruktsiya i razmery

4. STO 365545010392014 Ankernye krepleniya k betonu s primeneniem ankerov HILTI. Raschyot i konstruirovanie

5. M.S. Hoehler, P. Mahrenholtz, R. Eligehausen ACI Structural Journal 108 238-247 (2011)

6. P. Mahrenholtz, R. Eligehausen Nuclear Engineering and Design 287 48-56 (2015)

7. M. Rodriguez, D. Lotze, J.H. Gross, Y.G. Zhang, R.E. Klingner, H.L. Graves Structural Journal 98 511-524 (2001)

8. M. Hoehler Behavior and Fastening to Concrete for use in Seismic Applications, Dissertation, IWB, University of Stuttgart (2006)

9. A.V. Granovskij, L.B. Mirskoj Sejsmostojkoe stroitelstvo Bezopasnost sooruzhenij 2 39-42 (2012)

10. A.V. Granovskij, D.A. Kiselev Sejsmostojkoe stroitelstvo Bezopasnost sooruzhenij 1 43-45 (2012)

11. P. Mahrenholz Experimental Performance and Recommendations for Qualification of Post-installed Anchors for Seismic Applications, Dissertation, IWB, University of Stuttgart (2012).

12. GOST R 584302019 Ankery mekhanicheskie i kleevye dlya krepleniya v betone v sejsmicheskih rajonah. Metody ispytanij

13. D.A. Kiselev Prochnost $i$ deformativnost ankernogo krepezha pri dejstvii staticheskoj $i$ dinamicheskoj nagruzok, Dissertatsiya na soiskanie uchenoj stepeni k t n, Moscow, TSNIISK im V A Kucherenko.

14. A.V. Granovskij, M.O. Pavlova, V. Ch. Laskevich Sejsmostojkoe stroitelstvo Bezopasnost sooruzhenij 4 6-7 (2000)

15. V.D. Nasonkin, A.V. Granovskij, M.O. Pavlova Sejsmostojkoe stroitelstvo Bezopasnost sooruzhenij 5 21-23 (2000)

16. A.V. Granovskij, D.A. Kiselev, A.G. Aksenova Beton i zhelezobeton 2 17-20 (2006)

17. STO 365545010522017 Ankernye krepleniya k betonu. Pravila ustanovleniya normiruemyh parametrov

18. GOST R 567312015 Ankery mekhanicheskie dlya krepleniya v betone. Metody ispytanij.

All tests were carried out using research equipment of The Head Regional Shared Research Facilities of the Moscow State University of Civil Engineering. 